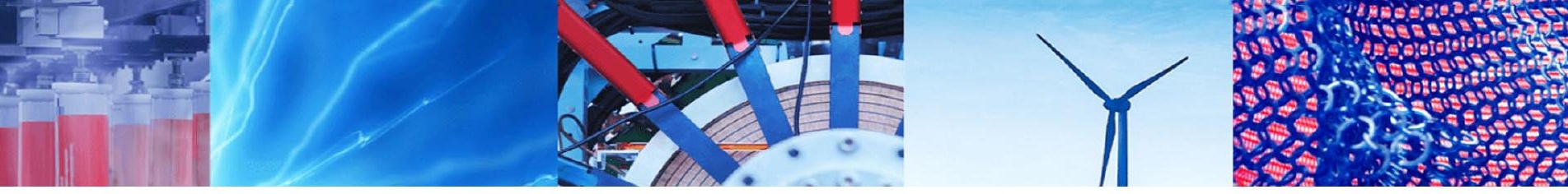

Research Article

\title{
Spatial and temporal variations of faecal indicator bacteria in Lake Bunyonyi, South-Western Uganda
}

\author{
Alex Saturday ${ }^{1,2}$ (1) $\cdot$ Thomas J. Lyimo $^{1} \cdot$ John Machiwa ${ }^{3} \cdot$ Siajali Pamba ${ }^{3}$
}

Received: 10 February 2021 / Accepted: 3 June 2021

Published online: 10 June 2021

(c) The Author(s) 2021 OPEN

\begin{abstract}
Background Microbial water quality serves to indicate health risks associated with the consumption of contaminated water. Nevertheless, little is known about the microbiological characteristics of water in Lake Bunyonyi. This study was therefore undertaken to examine the spatial and temporal variations of faecal indicator bacteria (FIB) in relation to physicochemical parameters in Lake Bunyonyi. Result The FIB concentration was consistently measured during sampling months and correlated with each other showing the presumed human faecal pollution in the lake. The highest concentration values for $E$. coli $(64.7 \pm 47.3 \mathrm{CFU} / 100 \mathrm{~mL})$ and enterococci $(24.6 \pm 32.4 \mathrm{CFU} / 100 \mathrm{~mL}$ were obtained in the station close to the Mugyera trading centre. On a temporal basis, the maximum values were recorded during the rainy season in October $2019(70.7 \pm 56.5 \mathrm{CFU} / 100 \mathrm{~mL}$ for $\mathrm{E}$. coli and $38.44 \pm 31.8 \mathrm{CFU} / 100 \mathrm{~mL}$ for enterococci. FIB did not differ significantly among the study stations $(p>0.05)$ but showed significant temporal variations among the months $(p<0.05)$ with concentrations being significantly high in wet season than dry season $(U=794, p<0.0001$ for $E$. coli; $U=993.5, p=0.008$ for enterococci). Spearman's rank correlation revealed that FIB concentrations were significantly positively correlated with turbidity and DO concentration levels $(p<0.05)$. Approximately $97.2 \%$ of the water samples had $E$. coli and enterococci concentrations levels below USEPA threshold for recreational waters. Likewise, 98.1 and $90.7 \%$ of samples recorded $E$. coli and enterococci counts exceeding the UNBS, APHA, WHO and EU threshold values for drinking water. Conclusion The FIB counts show that the Lake Bunyonyi water is bacteriologically unsuitable for drinking unless it is treated since the FIB pose health risks to consumers. Besides, the water can be used for recreational purposes.
\end{abstract}

Keywords Faecal bacteria · Indicator bacteria · E. coli $\cdot$ Enterococci $\cdot$ Lake Bunyonyi $\cdot$ Uganda

\section{List of Abbreviations}

WHO World Health Organization

APHA American Public Health Association

FIB Faecal indicator bacteria

CFU Colony-forming unit

NTU Nephelometric turbidity unit

USEPA The United States Environment Protection Agency

\section{Background}

The microbiological quality of freshwater bodies serves to indicate health risks associated with the contamination of water by faecal sources [26]. Contamination of freshwater lakes can result from the influx of runoff from agricultural land after manure applications, faulty septic systems, and direct deposition from people, animals and wastewater discharge. The use of contaminated water for drinking, irrigation and recreation poses health risks to people.

\footnotetext{
$\triangle$ Alex Saturday, salex@kab.ac.ug | 'Department of Molecular Biology and Biotechnology, University of Dar Es Salaam, P.O. Box 35064, Dar es Salaam, Tanzania. ${ }^{2}$ Department of Environmental Sciences, Kabale University, P.O. Box 317, Kabale, Uganda. ${ }^{3}$ Department of Aquatic Sciences and Fisheries, University of Dar Es Salaam, P.O. Box 35064, Dar es Salaam, Tanzania.
}

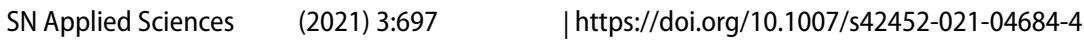


Globally, approximately 600 million people suffer annually from waterborne diseases after drinking contaminated water [14]. Consumption of safe and clean water has been increasingly viewed as the best alternative for increasing human safety against waterborne diseases. The bacteriological quality of water in the lake system is recognized as a major factor that affects surface water quality. Therefore, a lake whose water is supplied for drinking, recreation and livelihoods must be assessed to avoid threats from enteric pathogens [20].

Testing for every enteric pathogen is time-consuming and expensive, so regulatory agencies have focused on the enumeration of faecal indicator bacteria (FIB) to assess the bacteriological quality of freshwater sources [31]. Thus, understanding the source of faecal pollution in the lake system is vital as contamination from diverse sources poses varying risk levels. Human sewage and livestock faecal matter are the most high-risk sources of faecal contamination which may contain human-specific viruses and pathogens [17, 22].

The E. coli and enterococci bacteria are commonly used indicator microorganisms for bacteriological quality of water intended for various purposes. They are generally non-pathogenic and inhabit the gastrointestinal tract of warm- and cold-blooded animals. They are shed in faeces along with enteric pathogens. Thus, their measure shows the degree of faecal contamination. According to USEPA [31], the safety threshold for E. coli concentration in fresh recreational waters was established as a geometric mean of $235 \mathrm{CFU} / 100 \mathrm{~mL}$ in single samples and $126 \mathrm{CFU} / 100 \mathrm{~mL}$ in multiple samples. For enterococci, the safety threshold is at a geometric mean of $104 \mathrm{CFU} / 100 \mathrm{~mL}$ in single samples and $33 \mathrm{CFU} / 100 \mathrm{~mL}$ in multiple samples in a 30-day interval. The World Health Organization (WHO) guidelines for drinking water state that water intended to be used for drinking should be free from E.coli and enterococci [32].

Lake Bunyonyi is a major source of water, employment opportunities and a major tourist destination site in Western Uganda. Its watershed is a densely populated area with extensive subsistence farming. The major crops grown are: sweet potatoes, irish potatoes, beans, sorghum, cabbages [21], and barley was recently introduced in the northern part of the lake watershed. Besides, small scale fishing and aquaculture are also carried out in the lake water [18]. Thus, the livelihood activities of the people in the lake watershed largely depend on the health of the lake ecosystem. Lake Bunyonyi watershed is predominantly occupied by rural people whose pit latrines are constructed less than $20 \mathrm{~m}$ from the lake. Nevertheless, no study has been conducted to assess the bacteriological characteristics of water in the lake ecosystem, well knowing that the observed eutrophication induced by anthropogenic activities may jeopardize the ecological services this lake renders. Therefore, this study is the first of its kind regarding the current topic of research on Lake Bunyonyi. The main objective of this study was to examine the spatio-temporal variations in E. coli and enterococci concentrations in Lake Bunyonyi to provide a basis upon which necessary measures may be taken to preserve its ecosystem health.

\section{Materials and methods}

\subsection{Study area and sampling}

The study was conducted on Lake Bunyonyi which is shared by the districts of Kabale and Rubanda in Southwestern Uganda (Fig. 1). Geographically, Lake Bunyonyi is located between $1.2953^{\circ} \mathrm{S}$ and $29.9133^{\circ} \mathrm{E}$ and at an average altitude of $1973 \mathrm{~m}$ above sea level. The lake is long and narrow with a total surface area of $56 \mathrm{~km}^{2}$ with a maximum depth of $40 \mathrm{~m}$ [18]. The climate of the study area is warm and temperate influenced by altitude and latitude. It is characterized by a bimodal rainfall distribution with the long rainy season occurring between March and May. The short rains occur between October and November while June to August is the driest period. The mean annual rainfall ranges from 800 to $1000 \mathrm{~mm}$. The temperature in the lake catchment ranges from $23.7^{\circ} \mathrm{C}$ in March to $24.8^{\circ} \mathrm{C}$ in August [27].

Water samples were collected into $800 \mathrm{~mL}$ sterilized glass bottles with corks shielded with aluminium foil for the avoidance of any form of hand contamination. In total, 108 samples were collected from the nine study stations for 12 months (October 2019 - September 2020) for the determination of $E$. coli and enterococci concentrations. All the samples were labelled according to their respective site code (U1-U3, M1-M3 and L1-L3 for samples collected from stations located in the upper, middle and lower Bunyonyi sites (Table 1), respectively to get an overview of the entire lake understudy. All the samples were collected and stored in an icebox with an ice block and transported to the National Water and Sewerage Corporation (NWSC) central laboratories in Kampala for analysis within $24 \mathrm{~h}$. While in the laboratory, samples were stored at $4{ }^{\circ} \mathrm{C}$ in the refrigerator waiting for analysis.

\section{Analytical methods}

\subsection{Physicochemical analysis}

The physicochemical water quality parameters such as surface water temperature, DO, turbidity, and electrical conductivity $(E C)$ were measured on-site. DO was measured 


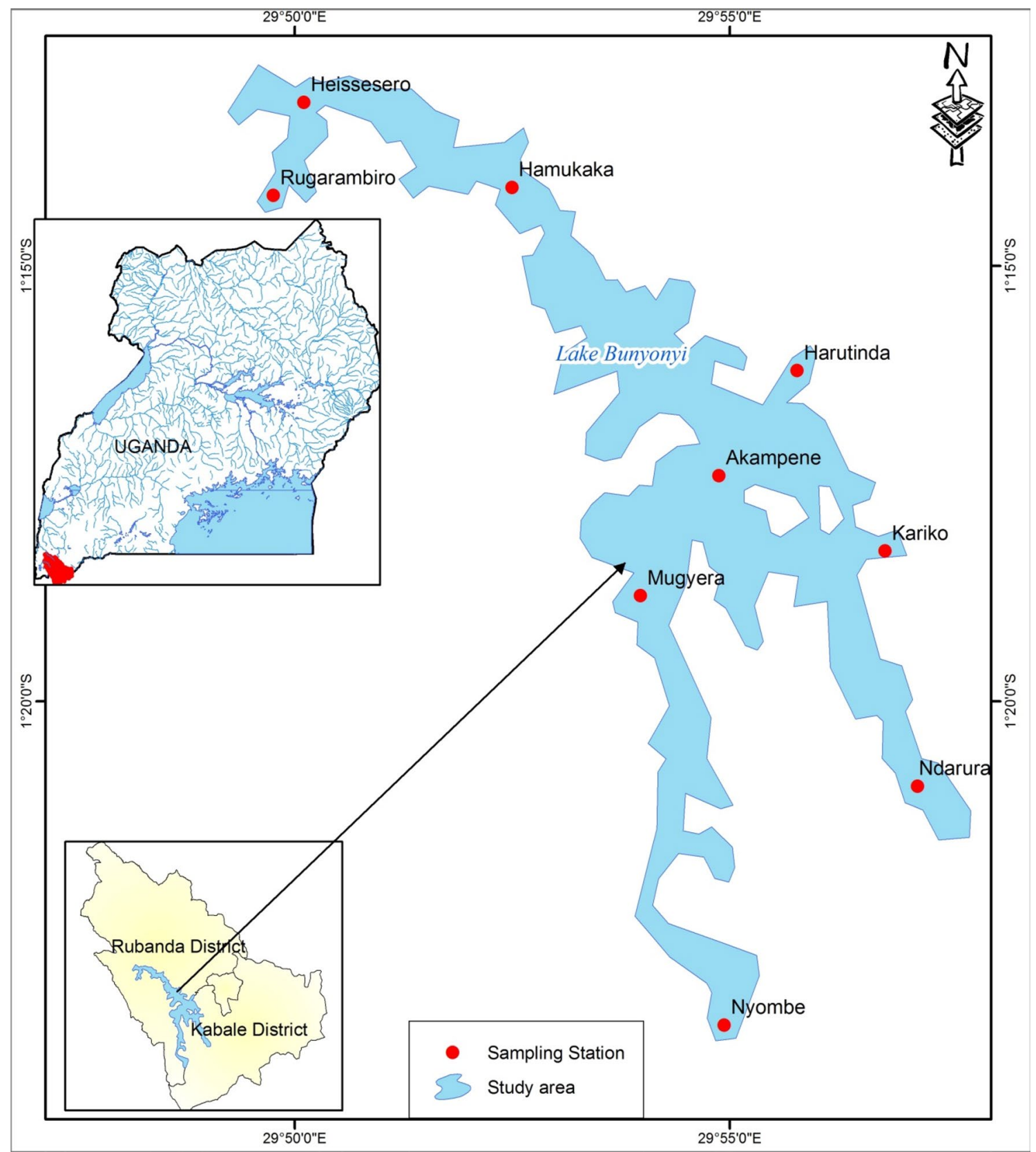

Fig. 1 Location Map of Lake Bunyonyi, Southwestern Uganda

using the DO meter (DO 5510 M.R.C model) while water temperature was measured using a temperature sensor in the $\mathrm{DO}$ meter. The $\mathrm{pH}$ and $\mathrm{EC}$ were measured using a water-resistant hand-held $\mathrm{pH}$ meter (HI8314 HANNA instruments) and using a conductivity meter (HI 9033 HANNA instruments), respectively and the turbidity measured was using a turbidity meter (2100P, Hach). All measurements were done in triplicate and the average values are reported herein.

To measure $\mathrm{NO}_{3}-\mathrm{N}$ concentration in water samples, the content of one pillow Nitraver 6 was added to $25 \mathrm{ml}$ of water sample in a graduated mixing cylinder. The mixture was covered with palm, held firmly and inverted several times to dissolve the powder. Between $10 \mathrm{~min}$ and $2 \mathrm{~h}$ afterwards, absorbance was measured at $543 \mathrm{~nm}$ at UV spectrophotometer (DR6000, Hach Laboratory Instruments). For SRP determination in the water sample, $50 \mathrm{~mL}$ of filtered water sample was mixed with ammonium molybdate to form molybdo-phosphoric acid in a dry $125 \mathrm{~mL}$ Erlenmeyer flask. The acid was reduced by ascorbic acid to a blue complex (molybdenum blue). Thereafter, the colour intensity proportional to the concentration of 
Table 1 Sampling site location for E. coli and Enterococci parameters

\begin{tabular}{|c|c|c|c|c|}
\hline \multirow[t]{2}{*}{ Study site } & \multirow[t]{2}{*}{ Station code } & \multirow[t]{2}{*}{ Station name } & \multicolumn{2}{|l|}{ Location } \\
\hline & & & latitudes & Longitudes \\
\hline \multirow[t]{3}{*}{ Upper Bunyonyi } & U1 & Nyombe & $1^{\circ} 23^{\prime} 50.16^{\prime \prime} \mathrm{S}$ & $29^{\circ} 55^{\prime} 08.80^{\prime \prime} \mathrm{E}$ \\
\hline & U2 & Ndarura & $1^{\circ} 20^{\prime} 58.55^{\prime \prime} \mathrm{S}$ & $29^{\circ} 57^{\prime} 25.47^{\prime \prime} \mathrm{E}$ \\
\hline & U3 & Kariko & $1^{\circ} 18^{\prime} 16.30^{\prime \prime} \mathrm{S}$ & $29^{\circ} 56^{\prime} 46.96^{\prime \prime} \mathrm{E}$ \\
\hline \multirow[t]{3}{*}{ Middle Bunyonyi } & M1 & Harutinda & $1^{\circ} 16^{\prime} 14.98^{\prime \prime} \mathrm{S}$ & $29^{\circ} 56^{\prime} 16.48^{\prime \prime} \mathrm{E}$ \\
\hline & M2 & Akampene & $1^{\circ} 17^{\prime} 37.60^{\prime \prime} \mathrm{S}$ & $29^{\circ} 55^{\prime} 02.47^{\prime \prime} \mathrm{E}$ \\
\hline & M3 & Mugyera & $1^{\circ} 19^{\prime} 05.62^{\prime \prime} \mathrm{S}$ & $29^{\circ} 54^{\prime} 09.76^{\prime \prime} \mathrm{E}$ \\
\hline \multirow[t]{3}{*}{ Lower Bunyonyi } & L1 & Heissesero & $1^{\circ} 13^{\prime} 00.32^{\prime \prime S}$ & $29^{\circ} 49^{\prime} 53.56^{\prime \prime} \mathrm{E}$ \\
\hline & L2 & Rugarambiro & $1^{\circ} 14^{\prime} 20.11^{\prime \prime} \mathrm{S}$ & $29^{\circ} 50^{\prime} 04.32^{\prime \prime} \mathrm{E}$ \\
\hline & L3 & Hamukaka & $1^{\circ} 14^{\prime} 05.76^{\prime \prime} \mathrm{S}$ & $29^{\circ} 52^{\prime} 29.77^{\prime \prime} \mathrm{E}$ \\
\hline
\end{tabular}

phosphate in the sample was measured by the spectrophotometer at a wavelength of $880 \mathrm{~nm}$ [3]. The $\mathrm{NO}_{3}-\mathrm{N}$ and SRP concentration values were recorded directly from DR 6000 Spectrophotometer in the laboratory.

\subsection{Bacteriological analysis}

The membrane filtration technique was used for the determination of FIB ( $E$. coli and enterococci) concentrations in water samples following APHA [3] standards. Determination of $E$. coli was done by filtration of $100 \mathrm{~mL}$ of water samples through a $0.45 \mu \mathrm{m}$ millipore filter membrane. After filtration, the filters were placed on Chromogenic Coliform Agar (Oxoid Ltd, UK) prepared following manufacturer instructions and then incubated at $44.5^{\circ} \mathrm{C}$ for 18-24 h. E. coil numbers per $100 \mathrm{ml}$ of a sample were computed as per APHA [3].

For the case of enterococci, $100 \mathrm{~mL}$ of water sample was also filtered in the same way as above. However, the membrane filter was placed on Chromogenic agar media (Oxoid Ltd, UK) for enterococci growth and incubated at $41{ }^{\circ} \mathrm{C} \pm 0.5^{\circ} \mathrm{C}$ for $48 \pm 3 \mathrm{~h}$. Thereafter, the membrane filters were then transferred to a differential medium Esculin Iron Agar (EIA) and then incubated at $41^{\circ} \mathrm{C} \pm 0.5^{\circ} \mathrm{C}$ for $30 \mathrm{~min}$. The enterococci colonies on the Me-EIA agar membrane which appeared pink to red on the filter membrane paper developed into black or reddish-brown precipitate on transfer to EIA on the underside of the filter to verify enterococci. All the bacterial count per $100 \mathrm{ml}$ of a water sample analyzed was computed following the standard procedures for microbial analysis by APHA [3].

\subsection{Statistical analysis of data}

The collected data were analyzed using Statistica version 10 [7]. The Kruskal-Wallis test was conducted to determine differences between study sites, within sampling months. The differences between sites addressed spatial variations while differences within sampling months addressed temporal variations. Mann-Whitney $\mathrm{U}$ test was used to determine whether there significant differences in FIB concentrations between the dry season and rainy season. Spearman rank correlation was performed to establish whether there exists a relationship between FIB concentrations and physicochemical parameters. All statistical tests were considered significant at a confidence level of $95 \%(p<0.05)$.

\section{Results}

\subsection{Physicochemical characterization of study sites}

The mean values of the physical and nutrient parameters in the study stations are summarized in Table 2. The water temperature, $\mathrm{DO}, \mathrm{pH}$, turbidity, EC and SRP varied from $20.9 \pm 1.1$ to $21.7 \pm 1.5^{\circ} \mathrm{C}$, $6.6 \pm 1.2-7.2 \pm 1.7 \mathrm{mg} / \mathrm{L}, \quad 7.4 \pm 0.5-7.9 \pm 0.6$, $2.8 \pm 0.6-4.3 \pm 1.6 \mathrm{NTU}, 241.75 \pm 11.5-266.8 \pm 61.9 \mu \mathrm{S} / \mathrm{cm}$, and $0.05 \pm 0.02-0.18 \pm 0.26 \mathrm{mg} / \mathrm{L}$, respectively (Table 2 ). The mean $\mathrm{NO}_{3}-\mathrm{N}$ values were uniformly distributed across sampling stations $(0.01 \pm 0.01 \mathrm{mg} / \mathrm{L})$. Statistically, no significant differences in the mean water temperature, DO, $\mathrm{EC}$, water turbidity, $\mathrm{pH}, \mathrm{NO}_{3}-\mathrm{N}$, and SRP between study stations were observed (Fig. 2) $(p>0.05)$.

\subsection{Spatial variation in E. coli and enterococci concentration}

Across the stations, FIB counts ranged from 0 to $182 \mathrm{CFU} / 100 \mathrm{~mL}$ for E. coli (Fig. 3) and 0 to $105 \mathrm{CFU} / 100 \mathrm{~mL}$ for enterococci (Fig. 4). The highest mean value for $E$. coli $(64.7 \pm 47.3 \mathrm{CFU} / 100 \mathrm{~mL})$ and enterococci $(24.6 \pm 32.4 \mathrm{CFU} / 100 \mathrm{~mL})$ were obtained at Mugyera (M3) station (Fig. 2). The least concentration values for $E$. coli $(5.5 \pm 7 \mathrm{CFU} / 100 \mathrm{~mL})$ and enterococci 
Table 2 Physicochemical parameters variation at different sampling stations. Mean values \pm standard deviation obtained from different months $(n=12)$

\begin{tabular}{llllllll}
\hline Station & Temp $\left({ }^{\circ} \mathrm{C}\right)$ & $\mathrm{DO}(\mathrm{mg} / \mathrm{L})$ & $\mathrm{EC}(\mu \mathrm{S} / \mathrm{cm})$ & Turb $(\mathrm{NTU})$ & $\mathrm{pH}$ & $\mathrm{NO} \mathrm{S}_{3} \mathrm{~N}(\mathrm{mg} / \mathrm{L})$ & $\mathrm{SRP}(\mathrm{mg} / \mathrm{L}$ \\
\hline Nyombe (U1) & $20.9 \pm 1.1$ & $6.7 \pm 1.4$ & $241.8 \pm 11.5$ & $3.1 \pm 1.2$ & $7.5 \pm 0.5$ & $0.01 \pm 0.01$ & $0.18 \pm 0.26$ \\
Ndarura (U2) & $21.7 \pm 1.4$ & $6.8 \pm 1.4$ & $243.3 \pm 7.0$ & $2.8 \pm 0.6$ & $7.7 \pm 0.5$ & $0.01 \pm 0.01$ & $0.11 \pm 0.20$ \\
Kariko (U3) & $21.7 \pm 1.5$ & $7.0 \pm 1.3$ & $247.7 \pm 12.3$ & $3.2 \pm 1.2$ & $7.8 \pm 0.4$ & $0.01 \pm 0.01$ & $0.05 \pm 0.02$ \\
Harutinda (M1) & $21.3 \pm 1.5$ & $7.2 \pm 1.7$ & $266.8 \pm 61.9$ & $3.8 \pm 1.7$ & $7.7 \pm 0.4$ & $0.01 \pm 0.01$ & $0.05 \pm 0.02$ \\
Akampene (M2) & $21.3 \pm 1.5$ & $6.8 \pm 1.0$ & $243.7 \pm 8.1$ & $2.8 \pm 0.6$ & $7.9 \pm 0.6$ & $0.01 \pm 0.01$ & $0.09 \pm 0.13$ \\
Mugyera (M3 & $21.3 \pm 1.6$ & $6.5 \pm 1.2$ & $241.1 \pm 11.1$ & $4.3 \pm 1.6$ & $7.4 \pm 0.5$ & $0.01 \pm 0.01$ & $0.05 \pm 0.02$ \\
Heissesero (L1) & $21.0 \pm 1.6$ & $6.9 \pm 1.3$ & $245.2 \pm 8.6$ & $2.9 \pm 0.8$ & $7.8 \pm 0.7$ & $0.01 \pm 0.01$ & $0.05 \pm 0.03$ \\
Rugarambiro (L2) & $21.2 \pm 1.4$ & $7.0 \pm 1.3$ & $245.8 \pm 7.3$ & $3.2 \pm 0.8$ & $7.7 \pm 0.5$ & $0.01 \pm 0.01$ & $0.14 \pm 0.33$ \\
Hamukaka (L3) & $20.9 \pm 1.5$ & $6.6 \pm 1.2$ & $244.0 \pm 7.6$ & $3.6 \pm 1.2$ & $7.7 \pm 0.7$ & $0.01 \pm 0.01$ & $0.05 \pm 0.02$ \\
\hline
\end{tabular}

Fig. 2 Mean FIB counts across the different study stations during the study period (October 2019-September 2020)

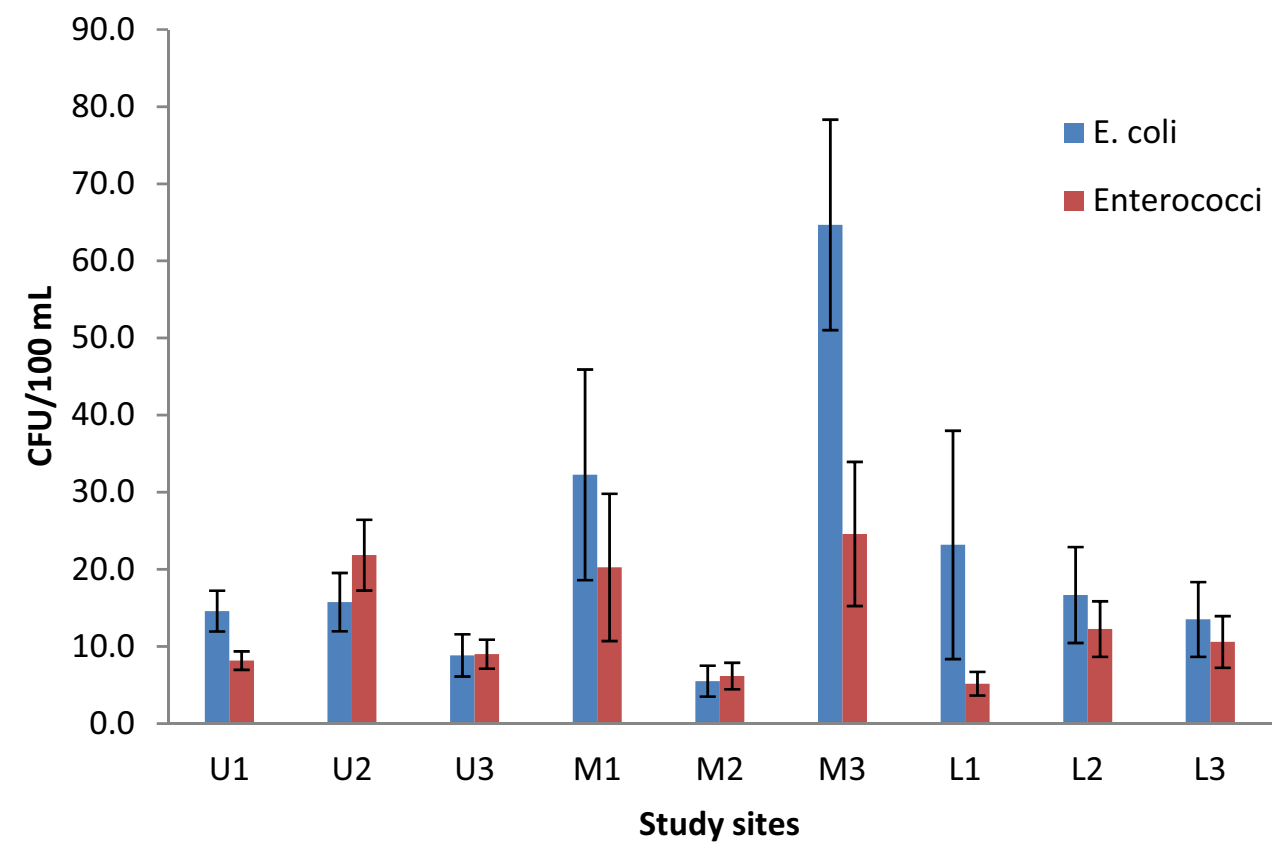

$(5.2 \pm 5.3 \mathrm{CFU} / 100 \mathrm{~mL})$ were obtained at Akampene (M2) and Heissesero (L1) stations, respectively (Fig. 2). Indeed, Kruskal-Wallis test revealed significant differences in $E$. coli concentration values across stations $(H(8$, $\mathrm{N}=108)=32.004, p=0.0001)$. Enterococci concentration were not significantly different across study stations $(H$ (8, $N=108)=13.8, p=0.087$ ).

\subsection{Temporal variation of E. coli and enterococci concentration}

The results indicate the heterogeneous distribution of faecal contamination between seasons for both E.coli and enterococci during the study period. The highest level of FIB count was recorded in October 2019 with a mean value of $70.7 \pm 56.5 \mathrm{CFU} / \mathrm{mL}$ for $E$. coli and $38.4 \pm 31.8 \mathrm{CFU} / 100 \mathrm{~mL}$ for enterococci. On the other hand, the least FIB concentration was obtained in August 2020 with a mean value of $5.4 \pm 7.5 \mathrm{CFU} / 100 \mathrm{~mL}$ for E. coli and $2.3 \pm 2.2 \mathrm{CFU} /$ $100 \mathrm{~mL}$ for enterococci bacteria (Fig. 5). Statistically, Kruskal-Wallis test revealed significant differences in FIB counts between study months $(H(11, N=108)=37.4$, $p<0.001$ for E. coli; $H(11, \mathrm{~N}=108)=56.6, p<0.001$ for enterococci). Considering wet and dry seasons, the mean FIB concentration of the wet season $(29.8 \pm 40.4$ CFU/100 MI for E. coli; $16.7 \pm 22.0 \mathrm{CFU} / 100 \mathrm{~mL}$ ) were significantly higher than the values $(10.3 \pm 15.3 \mathrm{CFU} / 100 \mathrm{~mL}$ for $E$. coli; $8.0 \pm 9.4 \mathrm{CFU} / 100 \mathrm{~mL}$ ) of the dry season (Table 3). Indeed, the Mann-Whitney $\mathrm{U}$ test revealed significant differences in FIB concentration between seasons $(U=794, p<0.001$ for $E$. coli; $U=993.5, p=0.008$ for enterococci).

The Spearman's rank correlation was computed to establish whether there were significant relationship between 


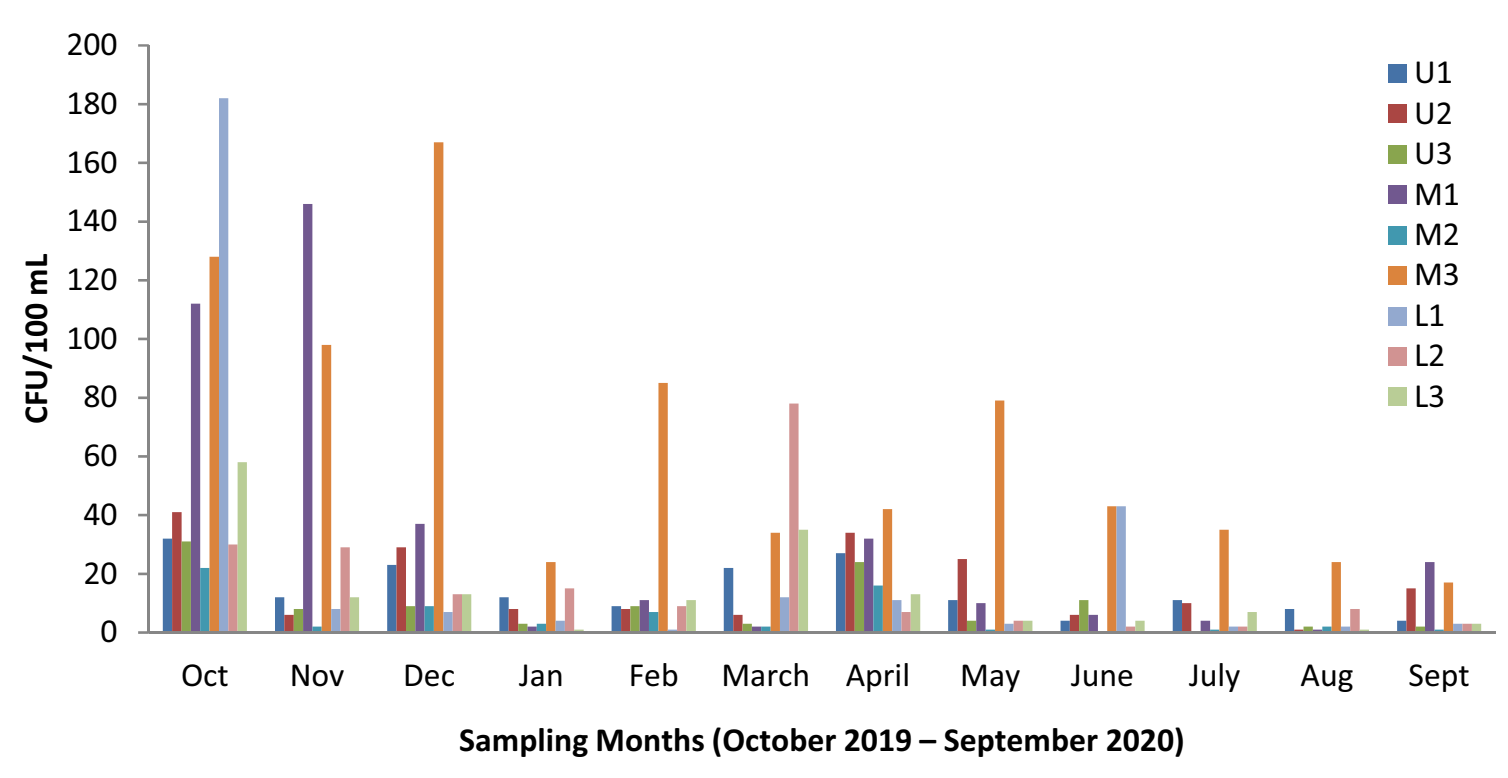

Fig. 3 Monthly variation of E. coli counts across stations during the study period (October 2019-September 2020)

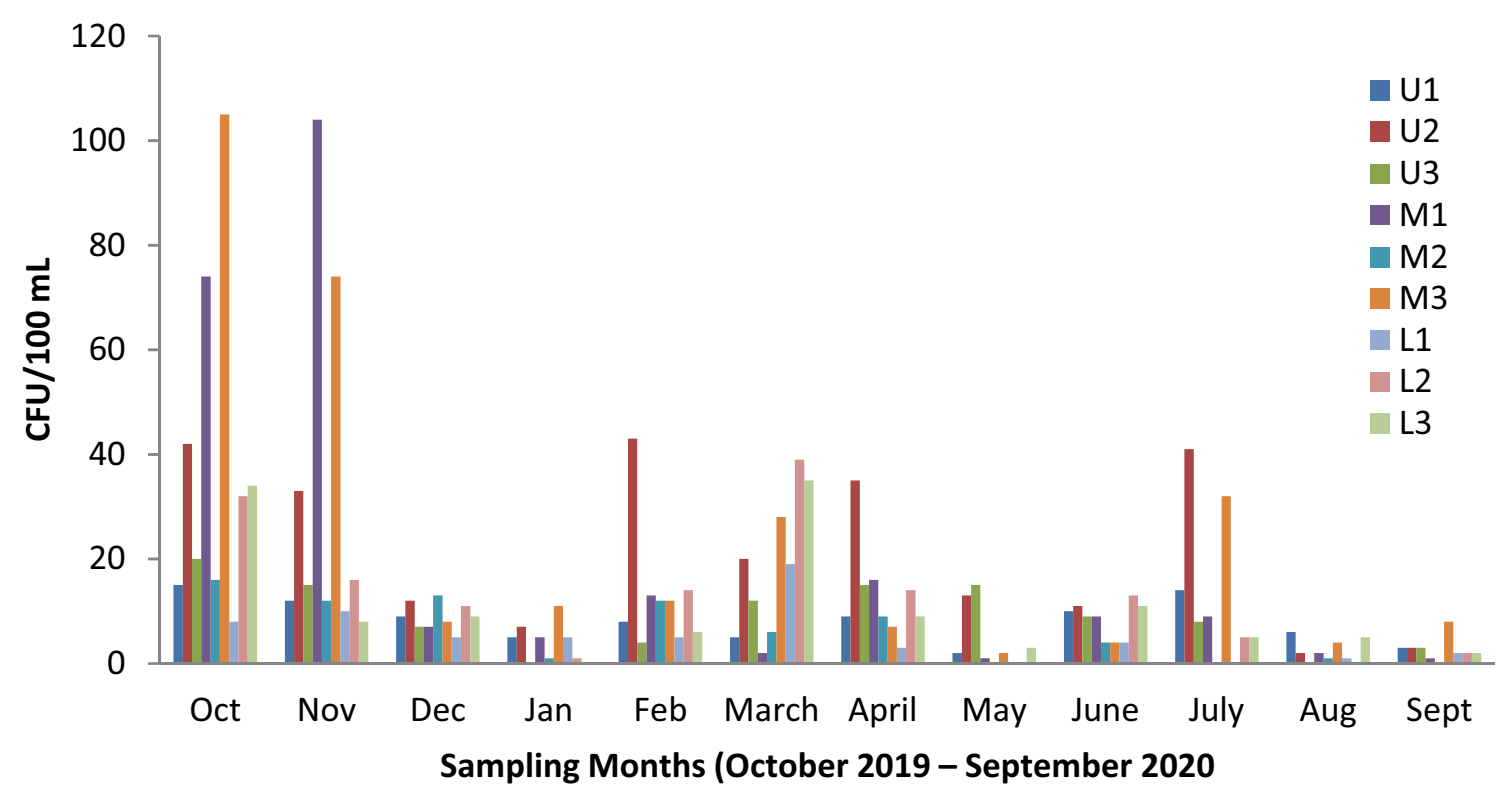

Fig. 4 Monthly variation of Enterococci counts across stations during the study period (October 2019-September 2020)

the measured FIB concentration and the physicochemical parameters. The correlation results (Table 4) indicated that $E$. coli was significantly positively correlated with $\mathrm{DO}(r s=0.390$, $p<0.05)$ and turbidity $(r s=0.438, p<0.05)$ but significantly negatively correlated with $\mathrm{pH}(r s=-0.201, p<0.05)$. Likewise, enterococci was significantly positively correlated with DO $(r s=0.365, p=<0.05)$ and turbidity $(r s=0.211, p<0.05)$ (Table 4).

\section{Discussion}

\subsection{Physicochemical characteristics of Lake Bunyonyi}

The results of physicochemical conditions of Lake Bunyonyi showed insignificant differences among stations but varied with seasons and the values were within the range 


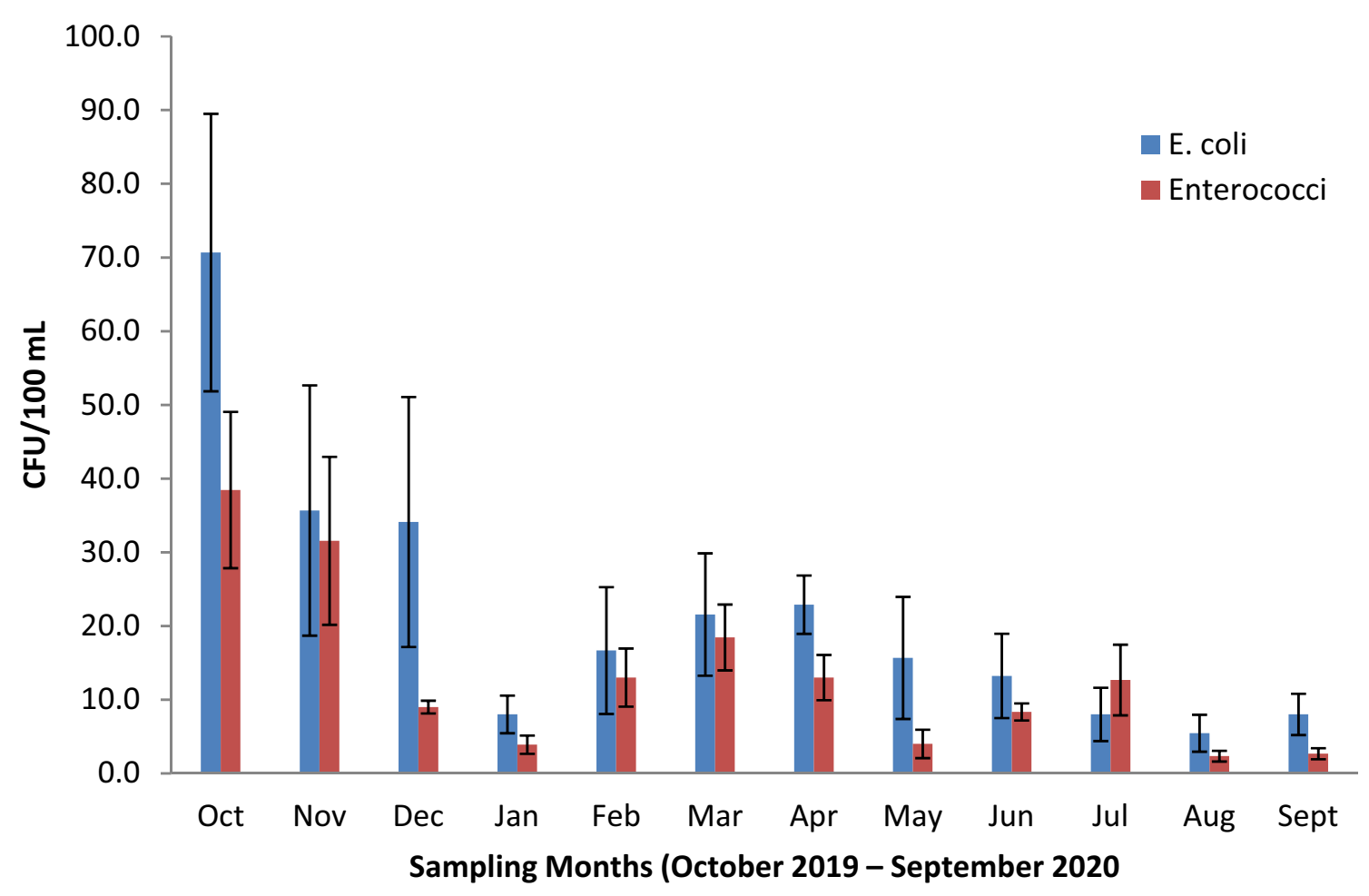

Fig. 5 Mean FIB concentration values in Lake Bunyonyi during the study period (October 2019-September 2020)

Table 3 Seasonal variation of FIB in Lake Bunyonyi (October 2019-September 2020)

\begin{tabular}{|c|c|c|c|c|c|c|c|c|}
\hline \multirow[t]{2}{*}{ Season } & \multicolumn{4}{|l|}{ E. coli } & \multicolumn{4}{|c|}{ Enterococci } \\
\hline & Means & Std. Dev. & Min & Max & Means & Std. Dev. & Min & $\operatorname{Max}$ \\
\hline Wet season & 29.8 & 40.4 & 1.0 & 182.0 & 16.7 & 22.0 & 0.0 & 105.0 \\
\hline Dry season & 10.3 & 15.3 & 0.0 & 85.00 & 8.00 & 9.40 & 0.0 & 43.00 \\
\hline All Grps & 21.7 & 33.7 & 0.0 & 182.0 & 13.1 & 18.3 & 0.0 & 105.0 \\
\hline
\end{tabular}

The mean FIB values were significantly different between seasons $(p<0.05)$

Table 4 Correlation analysis for FIB and environmental parameters; Values with an asterisk are significant at $p<0.05$

\begin{tabular}{|c|c|c|c|c|c|c|c|c|c|}
\hline Variables & E. coli (CFU/100 mL) & $\begin{array}{l}\text { Enterococci } \\
\text { (CFU/100 mL) }\end{array}$ & Temp $\left({ }^{\circ} \mathrm{C}\right)$ & $\mathrm{DO}(\mathrm{mg} / \mathrm{L})$ & $\mathrm{EC}(\mu \mathrm{S} / \mathrm{cm})$ & Turb (NTU) & $\mathrm{pH}$ & $\mathrm{NO}_{3}-\mathrm{N}(\mathrm{mg} / \mathrm{L})$ & $\mathrm{SRP}(\mathrm{mg} / \mathrm{L})$ \\
\hline E. coli & 1 & & & & & & & & \\
\hline Enterococci & & 1 & & & & & & & \\
\hline Temp & -0.134 & -0.056 & 1 & & & & & & \\
\hline DO & $0.390^{*}$ & $0.365^{*}$ & $0.194^{*}$ & 1 & & & & & \\
\hline $\mathrm{EC}$ & 0.065 & 0.125 & 0.579 & $0.361^{*}$ & 1 & & & & \\
\hline Turbidity & $0.438^{*}$ & 0.211 & -0.033 & $0.471^{*}$ & 0.164 & 1 & & & \\
\hline $\mathrm{pH}$ & $-0.201^{*}$ & -0.153 & 0.153 & $0.402^{*}$ & -0.001 & 0.108 & 1 & & \\
\hline $\mathrm{NO}_{3}-\mathrm{N}$ & -0.068 & 0.082 & $-0.197^{*}$ & 0.048 & -0.079 & $0.300^{*}$ & $0.194^{*}$ & 1 & \\
\hline SRP & -0.144 & -0.047 & $0.300^{*}$ & 0.146 & 0.178 & -0.135 & 0.138 & $-0.327^{*}$ & 1 \\
\hline
\end{tabular}

$\mathrm{pH}=$ Water $\mathrm{pH}, E C$ Electric conductivity, $\mathrm{DO}$ Dissolved Oxygen, Temp= surface water temperature, $\mathrm{NO}_{3}-\mathrm{N}$ Nitrate $-\mathrm{Nitrogen}, \mathrm{SRP}$ Soluble Reactive Phosphorus 
of previous studies on lakes in Uganda and other countries which share similar characteristics $[27,28]$. Surface water temperatures did vary significantly between stations perhaps due to the differences in the study locations and slight differences in the sampling time. The significant temporal variations are attributed to the dynamics in seasonal weather patterns within the Lake catchment area. Besides, the Lake understudy is situated between steep hills associated with several barriers that limit solar radiation on the surface waters of the Lake that would otherwise increase the water temperature. The recorded water temperature range corresponded with that reported in the previous study by Tibihika et al. [27] in Lake Bunyonyi and other minor lakes of the Kigezi sub-region. The dissolved oxygen (DO) levels were relatively low which is attributed to a higher rate of decomposition, especially in the wet season. Nevertheless, the observed DO range do not cause stress to aquatic organisms and can rarely cause mortality and reduction of the sensitive species [16]. Similar to our study results, DO levels of 5.7 and $5.7 \mathrm{mg} / \mathrm{L}$ have been reported by Tiémoko et al. [28] at Lake Taabo and Kossou, respectively. Likewise, DO levels across the study stations corroborated with those of Hughes [11] in Lake Bunyonyi.

The recorded EC fell below the WHO maximum permissible limits for freshwater bodies $(<1500 \mu \mathrm{S} / \mathrm{cm})$. These results indicate out rightly that water in the Lake understudy is not considerably ionized and has a relatively low ionic concentration level. Similar to study results, Edoreh et al. [9] reported slightly lower values across sampling stations in the Ugbevwe pond than the observed values in the present study. Turbidity levels were high in the wet season than in the dry season. These values were slightly higher than those reported by Anjusha et al. [2] with a mean turbidity range of 2.5-3.9 NTU in the Periyar River. The high turbidity level may indicate continuous terrestrial influence from rain runoff which carries faecal material and other debris into the Lake ecosystem. Besides, the recorded turbidity level could be attributed to cultivation coupled with infrastructural development on the Lakeshores; all of which accelerate soil erosion and sedimentation, and the resulting suspended solids are deposited into the lake system through surface runoff. The turbidity range values fell within the WHO permissible limit $(<10 \mathrm{NTU})$ for surface waters (WHO, 2017), indicative of uncompromised water quality based on turbidity level. The $\mathrm{pH}$ levels values were not significantly different across the study sites and were within the WHO maximum permissible limits (6.5-9) for the health ecosystem (WHO 2017). Freshwater lakes with a $\mathrm{pH}>7$ are alkaline and are dependent on the formation and nature of soils close to the water source or bedrock [27].

The $\mathrm{NO}_{3}-\mathrm{N}$ concentration values didn't exceed $1 \mathrm{mg} / \mathrm{L}$; the $\mathrm{WHO}$ recommended $\mathrm{NO}_{3}-\mathrm{N}$ limits for drinking water
(WHO 2017). These results may be attributed to the organic matter decomposition, activities of nitrogen-fixing bacteria in the Lake and surface runoff during heavy rainfall events. Similarly, Wang et al. (2020) reported high $\mathrm{NO}_{3}-\mathrm{N}$ concentration discharge into the DZ River in Houzhai catchment during the early rainfall events, which confirms the assertion that $\mathrm{NO}_{3}-\mathrm{N}$ level in lakes, tend to increase in the rainy season than the dry season. Variations in SRP values are attributed to the recent excessive use of fertilizers rich in phosphorus. Likewise, the recorded SRP values in the current study were slightly higher than values recorded by Tibihika et al. [27] at Lake Bunyonyi.

\subsection{Spatial variations of $E$. coli and enterococci concentration}

Significant spatial variation of $E$. coli concentration recorded during the study period indicates the heterogeneous distribution of faecal contamination. E. coli and enterococci counts at the study stations close to Mugyera and Harutinda Trading Centres were relatively high. This is possibly attributed to the rural people whose pit latrines are constructed less than $20 \mathrm{~m}$ from the lake, the possible contamination from the hotels constructed on the Lake peripheral (e.g. Crater Bay Cottage and Lake Bunyonyi Overland Resort) and the direct deposition of human faecal matter from swimmers since the Station near Harutinda Trading Centre is popular for swimming. The detection of E. coli and enterococci in water samples indicates faecal contamination by people and warm-blooded animals at various points. Although the levels of E. coli and enterococci were not higher than WHO recommended levels for swimming (33 enterococci and $200 \mathrm{E}$. coli), their presence indicate the possibility of occurrence of pathogenic bacteria that cause diseases such as gastroenteritis, cholera, dysentery and typhoid fever after ingestion of contaminated water [10]. Similar to our study results, previous studies attributed high FIB concentrations in the water close to sources from animals and sewage leakages, stormwater runoff, sewage overflows, application of manure in the water catchment area [10,25,34]. The effect of pit latrines on the quality of water was also reported by Islam et al. [13] in the Ganges Atrai floodplains of Bangladesh. It was found out that pit latrines enhanced bacterial contamination of adjacent shallow tube well water and that hydrogeological conditions played important role in the transport of FIB bacteria into the water [13].

\subsection{Temporal variations of $E$. coli and enterococci concentration}

The E. coli and enterococci counts were high during the wet season than the dry season. The observed high E. coli 
and enterococci counts in the wet season are linked to runoffs that carry fresh animal manure and human faecal matter. For instance, during heavy rainfall events, the surface runoff from campsites and business centres around the Lake introduce faecal contamination into surface waters. Besides, the stormwater in the Lake catchment sometimes overloads the capacity of toilet facilities and sewage systems, resulting in the unintentional leakage of faecal matter into the lake. Between October and December 20,019 before travel restrictions to Uganda due to the COVID-19 pandemic, the number of tourists visiting Lake Bunyonyi was at its highest peak and the Lake was fully utilized for recreation. Based on our one-year observations, it can be stated that the fluctuations in the number of tourists visiting Lake Bunyonyi are considered as one of the factors affecting the seasonal variation of FIB counts in the Lake. The results corroborate with many other findings on freshwater lakes; for example, Abia et al. [1], Aragonés et al. [4], Chávez-Díaz et al. [6], Edokpayi et al. [8] who reported higher FIB concentrations during the wet season than in the dry season. Similarly, Islam et al. [12] revealed a clear seasonality in FIB concentrations with higher mean concentrations occurring during the wet season (July to October) of 2014-2015. Nguyen et al. [24] attributed seasonal variations in FIB concentration to differences in land use activities, availability of nutrients, and human population growth. Similarly, Kayembe et al. [15] attributed high FIB concentration in water sources during the wet season to the higher runoff and overflow of onsite sanitation systems such as pit latrines and septic tanks into the water sources.

\subsection{Comparison of FIB concentration with water quality standards}

Results indicated that the Lake understudy was contaminated with faecal matter, whose FIB concentrations fell below the USEPA [30] threshold limit for recreational waters. According to the USEPA [30] directives, the safety threshold for E. coli concentration for fresh waters recreational activities was at a geometric mean of $126 \mathrm{CFU} / 100 \mathrm{~mL}$ in multiple samples and $235 \mathrm{CFU} / 100 \mathrm{~mL}$ in single samples. For enterococci concentrations, the safety threshold is at a geometric mean of $33 \mathrm{CFU} / 100 \mathrm{~mL}$ in multiple samples in a 30-day interval and $104 \mathrm{CFU} / 100 \mathrm{~mL}$ in single samples [30]. Our results, therefore, show that Lake Bunyonyi meets standards for recreational activities. Nevertheless, the use of Lake Bunyonyi for recreational purposes is recommendable since the FIB fell under the USEPA [30] threshold for recreational freshwater waters. On the other hand, the Lake's FIB counts exceeded the threshold limits for drinking water as per the EU Directive 2020/2184, WHO [32], APHA [3], and UNBS [29]. These guidelines require water for human consumption/drinking be free from E.coli and enterococci i.e. $0 \mathrm{CFU} / 100 \mathrm{~mL}[3,5,29,32]$. Similar to results, frequent violation of drinking water quality standards has been reported in previous studies [12, 23]. These results suggest treatment of water derived from Lake Bunyonyi to improve its safety for use. This is because of faecal contamination and possibly, pathogens that may cause waterborne disease outbreaks are present.

The Spearman rank correlation revealed a significant positive relationship between $E$. coli and enterococci in Lake Bunyonyi. These results were expected and indicate the effect of anthropogenic pressure in form of human and animal faecal matter inflow. Similarly, Lenart-Boroń et al. [19] associated FIB variability with surface runoff and supply of ions and bacteria emanating from snowmelt water. Similar results of significant positive correlations between E. coli and enterococci bacteria were already reported in other studies by Xue et al. [33], Jeon et al. [14], Tiémoko et al. [28] and Edokpayi et al. [8]. The significant positive correlation of FIB with DO and turbidity is possible because due to the mixing effect of the lake currents. Freshwater bodies with high DO and turbidity favor the survival of FIB concentrations for a relatively long period.

\section{Conclusion}

Based on the study results, we conclude that the observed E. coli and enterococci counts in the samples collected from Lake Bunyonyi render them bacteriologically unsuitable for drinking unless treated since they can pose health risks to consumers. The poorly constructed pit latrines in the lake's watershed and surface runoff following heavy rainfall events are the major sources of faecal pollution in the studied stations. Since $97.1 \%$ of analyzed water samples fell below the USEPA permissible intended level or water intended for recreational purposes, this water can be used for recreational purposes and other domestic purposes like washing. The detection of FIB far below the USEPA thresholds for bathing/swimming is enough to recommend the use of Lake Bunyonyi for recreational activities. The measured FIB concentrations were significantly high in the wet season implying that rainfall in the lake catchment increased FIB concentration in the lake water. The detected high levels of FIB at Mugyera and Harutinda stations ( between October and December 2019) are adequate to lure decision-makers and researchers to take strict measure to stop further deterioration, and conduct more research, respectively to ensure sustainability in the utilization of the Lake and safeguard the populace from the possible outbreak of water bone diseases. Additionally, creating local awareness is vital for the effective 
management of pollution and its health-associated risks such as the danger of swimming in faecal contaminated waters. Additionally, the detected levels of FIB across the study stations are adequate to lure decision-makers and researchers to take strict measures to stop further deterioration and conduct more research, respectively to ensure sustainability in the utilization of Lake Bunyonyi.

Acknowledgements We would like to thank NWSC, Kampala-Uganda for accepting us to use their laboratory facilities. We also wish to thank the communities living around Lake Bunyonyi for their support during the study.

Author contributions AS conceived and designed the study, collected and analyzed data, and drafted the manuscript: TJL, JM and SP contributed to the conception and design of the study, assisted in data interpretation and revision of the manuscript for intellectual content. All the authors read and approved the final manuscript for publication.

Funding The study was privately sponsored and is part of a $\mathrm{PhD}$ study for AS.

Data Availability All data generated and analyzed during this study are included in this published article.

\section{Declarations}

Conflict of interests The authors declare that they have no conflict of interest.

Open Access This article is licensed under a Creative Commons Attribution 4.0 International License, which permits use, sharing, adaptation, distribution and reproduction in any medium or format, as long as you give appropriate credit to the original author(s) and the source, provide a link to the Creative Commons licence, and indicate if changes were made. The images or other third party material in this article are included in the article's Creative Commons licence, unless indicated otherwise in a credit line to the material. If material is not included in the article's Creative Commons licence and your intended use is not permitted by statutory regulation or exceeds the permitted use, you will need to obtain permission directly from the copyright holder. To view a copy of this licence, visit http://creativecommons. org/licenses/by/4.0/.

\section{References}

1. Abia ALK, Ubomba-Jaswa E, Momba MNB (2015) Impact of seasonal variation on Escherichia coli concentrations in the riverbed sediments in the Apies River, South Africa. Sci Total Environ 537:462-469

2. Anjusha KV, James AM, Thankachan FA, Benny J, \& Hezakiel VB (2020) Assessment of Water Pollution Using GIS: A Case Study in Periyar River at Eloor Region. In Green Buildings and Sustainable Engineering (pp. 413-420). Springer.

3. APHA (2017) Standard methods for the examination of water and wastewater (23rd ed.). American Public Health Association. www.standardmethods.org

4. Aragonés L, López I, Palazón A, López-Úbeda R, García C (2016) Evaluation of the quality of coastal bathing waters in Spain through fecal bacteria Escherichia coli and Enterococcus. Sci Total Environ 566:288-297

5. Baudišová D, Kožíšek F (2021) New European union directive on drinking water. Water Manag Tech Econ Inf 63(1):15-17

6. Chávez-Díaz LV, Gutiérrez-Cacciabue D, Poma HR, Rajal VB (2020) Sediments quality must be considered when evaluating freshwater aquatic environments used for recreational activities. Int J Hyg Environ Health 223(1):159-170

7. De Sá JPM (2007) Applied statistics using SPSS, Statistica, MatLab and R. Springer Science and Business Media.

8. Edokpayi JN, Odiyo JO, Popoola EO, Msagati TA (2018) Evaluation of microbiological and physicochemical parameters of alternative source of drinking water: A case study of Nzhelele River South Africa. The Open Microbiol J 12:18

9. Edoreh JA, Inegbenosun CU, Elimhingbovo IO, Imoobe TOT (2019) Spatial and temporal variation in physicochemical parameters at Ugbevwe Pond, Oghara. Delta State Tropical Freshwater Biol 28(2):141-157

10. Graciaa DS, Cope JR, Roberts VA, Cikesh BL, Kahler AM, Vigar M, Hilborn ED, Wade TJ, Backer LC, Montgomery SP (2018) Outbreaks associated with untreated recreational water-the United States, 2000-2014. Morb Mortal Wkly Rep 67(25):701

11. Hughes RH (1992) A directory of African wetlands. IUCN.

12. Islam MMM, Hofstra N, Islam MdA (2017) The impact of environmental variables on faecal indicator bacteria in the Betna River Basin Bangladesh. Environ Proces 4(2):319-332. https:// doi.org/10.1007/s40710-017-0239-6

13. Islam MS, Mahmud ZH, Islam MS, Saha GC, Zahid A, Ali AZ, Hassan MQ, Islam K, Jahan H, Hossain Y (2016) Safe distances between groundwater-based water wells and pit latrines at different hydrogeological conditions in the Ganges Atrai floodplains of Bangladesh. J Health Popul Nutr 35(1):1-10

14. Jeon DJ, Pachepsky Y, Coppock C, Harriger MD, Zhu R, and Wells E (2020) Temporal stability of E. coli and Enterococci concentrations in a Pennsylvania creek. Environmental Science and Pollution Research, 27(4), 4021-4031.

15. Kayembe JM, Thevenon F, Laffite A, Sivalingam P, Ngelinkoto P, Mulaji CK, Otamonga JP, Mubedi Jl, Poté J (2018) High levels of faecal contamination in drinking groundwater and recreational water due to poor sanitation, in the sub-rural neighbourhoods of Kinshasa, the Democratic Republic of the Congo. Int J Hyg Environ Health 221(3):400-408

16. Keister JE, Winans AK, Herrmann B (2020) Zooplankton community response to seasonal hypoxia: a test of three hypotheses. Diversity 12(1):21

17. Keller R, Pratte-Santos R, Scarpati K, Martins S A, Loss SM, Fumian TM, Miagostovich MP, and Cassini ST (2019) Surveillance of enteric viruses and thermotolerant coliforms in surface water and Bivalves from a Mangrove Estuary in Southeastern Brazil. Food and Environ Virol, 1-9.

18. Kizza CL, Tenywa MM, Majaliwa JGM, Kansiime F, Magunda M, Nakileza B, Barasa B, Gabiri G, Sebuliba E, Nampijja J (2017) Land use/cover change patterns in highland ecosystems of Lake Bunyonyi catchment in western Uganda. Afr Crop Sci J 25(1):43-58

19. Lenart-Boroń A, Wolanin A, Jelonkiewicz CBD, Żelazny M (2016) Spatiotemporal variability in microbiological water quality of the Biallka River and its relation to the selected physicochemical parameters of water. Water Air Soil Pollut 227(1):22

20. Li C, Feng W, Chen H, Li X, Song F, Guo W, Giesy JP, Sun F (2019) Temporal variation in zooplankton and phytoplankton community species composition and the affecting factors in Lake Taihu-A large freshwater lake in China. Environ Pollut 245:1050-1057 
21. Maclean IM, Tinch R, Hassall M, \& Boar R (2003) Social and economic use of wetland resources: a case study from Lake Bunyonyi, Uganda. Environmental Change and Management Working Paper, 2003, 09.

22. Malla B, Ghaju Shrestha R, Tandukar S, Bhandari D, Thakali O, Sherchand JB, Haramoto E (2019) Detection of pathogenic viruses, pathogen indicators, and fecal-source markers within tanker water and their sources in the Kathmandu valley Nepal. Pathogens 8(2):81

23. Myers MR, Ambrose RF (2015) Saltmarsh reduces fecal indicator bacteria input to coastal waters in Southern California. Bulletin, Southern California Academy of Sciences 114(2):76-88

24. Nguyen HTM, Le QTP, Garnier J, Janeau JL, Rochelle-Newall E (2016) Seasonal variability of faecal indicator bacteria numbers and die-off rates in the Red River basin North Viet Nam. Sci Rep 6:21644

25. Seo M, Lee H, Kim Y (2019) Relationship between Coliform bacteria and water quality factors at Weir stations in the Nakdong River South Korea. Water 11(6):1171

26. Stocker MD, Rodriguez-Valentin JG, Pachepsky YA, Shelton DR (2016) Spatial and temporal variation of fecal indicator organisms in two creeks in Beltsville, Maryland. Water Qual Res J Can 51(2):167-179

27. Tibihika PDM, Okello W, Barekye A, Mbabazi D, Omony J, Kiggundu V (2016) Status of Kigezi minor Lakes: a limnological survey in the Lakes of Kisoro, Kabale and Rukungiri Districts. Int J Water Res Environ Eng 8(5):60-73

28. Tiémoko GJL, Ouattara NK, Kouamé CKY, Ouattara A, Gourène G (2020) Spatial and temporal variation of faecal indicator Bacteria in Three reservoirs of Ivory Coast (Taabo, Kossou and Fae). J Environ Sci 6(1):408-411

29. UNBS (2014) Uganda standards Template - World Trade Organization (1st ed.). Government of Uganda

30. USEPA (1986) Ambient water quality criteria for bacteria. The United States Environmental Protection Agency.

31. USEPA (2012) Recreational Water Quality Criteria. The United States Environmental Protection Agency.

32. WHO (2018) A global overview of national regulations and standards for drinking-water quality. World Health Organization.

33. Xue J, Lamar FG, Zhang B, Lin S, Lamori JG, Sherchan SP (2018) Quantitative assessment of Naegleria fowleri and fecal indicator bacteria in the brackish water of Lake Pontchartrain, Louisiana. Sci Total Environ 622-623:8-16. https://doi.org/10.1016/j.scito tenv.2017.11.308

34. Zehra A, Kaur S, Singh R, Gill JPS (2020) Surface water quality in Punjab, India: tracking human and farm animal-specific adenoviral contamination and correlation with microbiological and physiochemical parameters. Water Air Soil Pollut 231(11):534. https://doi.org/10.1007/s11270-020-04892-5

Publisher's Note Springer Nature remains neutral with regard to jurisdictional claims in published maps and institutional affiliations. 